virus and HIV we have formulated a policy to deal with it. In western Europe only $0 \cdot 1-0 \cdot 5 \%$ of the population are carriers of hepatitis B virus. Chronic carriage among intravenous drug abusers is much higher. The risk of acquiring infection with hepatitis $B$ virus after injury from an infected needle ranges from $6 \%$ to $30 \% .^{1}$ Infectivity depends on the concomitant presence of hepatitis B e antigen. ${ }^{2}$ The prevalence of HIV in the general population is much lower than that of hepatitis B virus, but again drug abusers are an at risk group. Although the risk of acquiring infection with HIV after an injury from a needle with the virus is less than $1 \%,{ }^{1}$ it is not negligible. ${ }^{3}$

Most hospital laboratories can test for or refer for testing for $\mathrm{HBsAg}$ and HIV antibodies, and results should be available within four hours. Although no treatment exists for infection with HIV, preventing infection with hepatitis $B$ virus by immunisation is possible. For passive immunity to be successful hepatitis B immunoglobulin should be administered within 48 hours. ${ }^{4}$ Its supply is limited at present, and it should therefore be reserved when possible for identified cases. Producing active immunity by hepatitis $B$ vaccination is also an effective means of prevention, particularly when vaccine is given early. ${ }^{5}$ We used both forms of immunisation.

Similar problems should be dealt with as follows. The nature and time of the needlestick injury should be noted. If the needle and syringe are available screening tests should be performed. If time permits no treatment is required until the results are known. If the results of screening are positive for hepatitis B virus, the needle and syringe are not available, or time does not permit the patient should be immunised against hepatitis $B$. If results are positive for HIV the patient should be followed up, though no treatment can be offered.

1 Centers for Disease Control. Recommendations for preventing transmission of HTLV III in the workplace. $M M W R$ 1985;34:22-32.

2 Shikata T, Karasawa T, Abe $K$, et al. Hepatitis B e antigen and infectivity of hepatitis B virus. F Infect Dis 1977;136:571-6.

3 Anonymous. Needlestick transmission of HTLV III from a patient infected in Africa. [Editorial.] Lancet 1984;ii:1376-7.

4 Reesink HW, Reerink-Brongers EE, Lafeber-Schul BJ, et al. Prevention of chronic HBsAg carrier state in infants of HBsAg positive mothers of hepatitis B immunoglobulin. Lancet 1979;ii:436-8. 5 Szumness W, Stevens CE, Harley EJ, et al. Hepatitis B vaccine: demonstration of efficacy in a controlled clinical trial in a high risk population in the United States. N Engl f Med 1980;303: 833-41.

(Accepted 29 June 1987)

Royal Liverpool Children's Hospitals

S S WALSH, MRCPI, DCH, registrar, accident and emergency department

A $M$ PIERCE, $M B, C H B$, locum consultant, accident and emergency department C A HART, MB, MRCPATH, professor of medical microbiology

Correspondence to: Dr S S Walsh, Royal Liverpool Children's Hospital (Alder Hey), Eaton Road, Liverpool 12.

\section{Disposal of plastic insulin syringes and needles}

Plastic insulin syringes will be available free on prescription from 1 September. The government has costed this exercise on the basis of "single use only." Local authorities have recently expressed concern about disposal methods, largely because of the acquired immune deficiency syndrome. For many years diabetics treated with insulin have been using, reusing, and disposing of plastic syringes without any reported problems. We surveyed 179 patients to ascertain their methods of disposing of syringes and their attitude to reusing them if they were made available free.

\section{Methods and results}

Patients were asked: (a) How do you dispose of your syringes, needles, and other "sharps"? (b) Do you think your method of disposal is safe? (c) Do you think you should be provided with disposal bins for sharps? (d) When syringes become available free on prescription will you change your frequency of reuse?

Methods of disposing of insulin syringes, needles, and other sharps-All 179 patients replaced the guard on the needle before disposal. Altogether 139 patients (78\%) disposed of their syringes in the household waste, which was then put into either a dustbin or a refuse disposal bag; 19 put them into a sealed tin or jar before disposal; eight used special sharps disposal bins; six incinerated them; and seven used other, more individual methods. These other methods included burial in concrete, long term storage in a drawer, obsessional wrapping in sealed parcels, and using syringes as floats and for dispersing bait for fishing (two people). In areas where plastic bags rather than dustbins were used people were conscious of the risk of foxes scattering the rubbish and therefore took extra care to disguise their syringes.
Safety of method of disposal -Altogether 139 patients considered their method of disposal to be safe. Forty patients were not entirely happy but saw no practical alternative: 32 were concerned about possible illicit reuse by intravenous drug abusers and only eight had considered that there might be a risk of needle stick injury. Because they did not consider themselves to be at high risk for the acquired immune deficiency syndrome they did not think that their syringes would be a risk to others.

Provision of disposal bins for sharps-Three quarters of the patients thought the provision of special bins a reasonable idea, although they were not convinced of its necessity; the remaining quarter thought it totally unnecessary. Asked whether they would be prepared to pay for such bins at a cost of $£ 1.50$ every six months, 72 patients said that they would not.

Reuse of syringes obtained free on prescription-Altogether 154 patients said that they would continue to reuse their syringes; the remaining 25 said that they would use them only once.

\section{Comment}

fin estimated 250000 diabetics receiving insulin have been reusing their plastic syringes and disposing of them for many years. We calculate that at least 11 million syringes and needles have therefore been disposed of every year in the household waste. Despite the presence of highly infectious agents, such as staphylococci and the hepatitis B antigen, no serious cases of transmitted infection have been reported. There have been occasional reports of minor injury from miscellaneous sharp objects and alarm at the discovery of syringes.

Is concern now justified? Human immunodeficiency virus is not easily transmitted. ' The vast majority of diabetics are negative for human immunodeficiency virus so their needles should present no risk. We therefore think that current disposal methods are safe and that concern is illogical and unnecessary. Clearly, however, patients positive for human immunodeficiency virus and hepatitis B should be provided with disposal bins for sharps.

In view of the figures for reuse of syringes we suggest that the government's costing is an overestimate. Perhaps the surplus could be put towards making blood glucose monitoring strips available free.

1 McEvoy M, Mortimer P, Shanson D, et al. Prospective study of clinical and ancillary staff with accidental exposure to blood or body fluids from patients infected with human immunodeficiency virus. Communicable Disease Report (in press).

(Accepted 21 fuly 1987)

Queen Mary's Hospital, Sidcup DA14 6LT

WILLIAM D ALEXANDER, MB, MRCP, consultant physician

C CORRIGAN, MA, MRCP, senior house officer

P TODD, MB, MRCP, senior house officer

M WELLS, SRN, diabetes nurse specialist

Correspondence to: Dr Alexander.

\section{Diuresis and syncope after renal angioplasty in a patient with one functioning kidney}

Percutaneous transluminal angioplasty is a widely accepted treatment for renal artery stenosis, offering a viable alternative to reconstructive surgery. ${ }^{1}$ The percutaneous approach may be the treatment of choice when the risks of surgery are considered to be unacceptable. The complications of this procedure include retroperitoneal haemorrhage, dissection of the renal artery, embolisation of dislodged fragments, and immediate profound hypotension.

We report a further complication: postural hypotension and syncope after a considerable postangioplasty diuresis.

\section{Case history}

A 74 year old man presented with a mild left hemiparesis in 1983, when his blood pressure was $220 / 130 \mathrm{~mm} \mathrm{Hg}$. Thirty years previously tec had apparently undergone a series of operations to remove large calculi from both kidneys. There was clinical evidence of peripheral vascular disease. He had been a heavy smoker and had poor respiratory reserve. His serum creatinine concentration was increased at $190 \mu \mathrm{mol} / \mathrm{l}$, with a creatinine clearance of $11 \mathrm{ml} / \mathrm{min}$. In the outpatient clinic his blood pressure was difficult to control; he was able to tolerate only slow release nifedipine $20 \mathrm{mg}$ twice daily and clonidine $50 \mu \mathrm{g}$ three times daily. His serum creatinine concentration slowly rose to $220 \mu \mathrm{mol} / \mathrm{l}$. 
In view of his deteriorating renal function, resistant hypertension, and widespread atheromatous disease, renal artery stenosis was suspected, and he underwent intravenous digital subtraction angiography. This showed a non-functioning right kidney and postostial stenosis of the left renal artery, with poststenotic dilatation. Renal vein renin studies showed no lateralisation, and peripheral concentrations were within the normal range. Because of his poor medical condition he was admitted for percutaneous transluminal renal angioplasty. Arterial angiography confirmed a tight stenosis with a pressure gradient of $100 \mathrm{~mm} \mathrm{Hg}$, falling to zero after dilatation. His blood pressure remained unchanged that evening at $200 / 120 \mathrm{~mm} \mathrm{Hg}$. There were no immediate postangioplasty complications, and his antihypertensive treatment was continued.

Over the next 24 hours he had a considerable diuresis and lost $2 \mathrm{~kg}$ in weight. On the morning after angioplasty, while sitting in a chair, he lost consciousness and was incontinent of urine; his pulse could barely be felt. On return to bed he regained consciousness; his blood pressure at this time was $130 / 80 \mathrm{~mm} \mathrm{Hg}$ and his pulse rate 80 beats/min and regular. There were no new neurological deficits, and his supine blood pressure settled at $180 / 100 \mathrm{~mm} \mathrm{Hg}$. His antihypertensive treatment was reduced, and he suffered no further syncopal attacks. On the morning of his syncopal attack his packed cell volume had increased from $0.34 \%$ to $0.39 \%$ and total protein concentration from $70 \mathrm{~g} / 1$ to $80 \mathrm{~g} / 1$. His serum creatinine concentration settled at $161 \mu \mathrm{mol} / \mathrm{l}$, and his blood pressure was easily controlled with slow release nifedipine $20 \mathrm{mg}$ twice daily at around $150 / 80 \mathrm{~mm}$ $\mathrm{Hg}$; antiplatelet treatment was also started.

\section{Comment}

This patient had a solitary functioning kidney with a stenosed arterial supply and normal plasma renin activity. This is comparable to the one kidney-one clip model of experimental renovascular hypertension, which is not renin dependent. ${ }^{2}$ After a technically successful dilatation his blood pressure did not fall until 12 hours later, after a large diuresis. This diuresis may have been induced by pressure or volume or related to poor tubular function.

We conclude that a large diuresis after percutaneous transluminal renal angioplasty may precipitate orthostatic hypotension. It is therefore important to monitor urine output and, if this is excessive, to ensure adequate volume replacement.

Hypovolaemia and hypotension should be avoided as such patients may also have cerebrovascular disease, and strokes may be precipitated. ${ }^{3}$ It is important to observe these precautions after angioplasty in patients with single functioning kidneys or bilateral renal artery stenosis.

We thank Dr D J Thomas, consultant neurologist, for his help.

1 Sos TA, Pickering TG, Sniderman K, et al. Percutaneous transluminal renal angioplasty in renovascular hypertension due to atheroma or fibromuscular dysplasia. $N$ Engl $\mathcal{J} \mathrm{Med}$ 1983;309:274-9.

2 Freeman RH, Davis JO, Seymour AA. Volume and vasoconstriction in experimental renovascular hypertension. Fed Proc 1982;41:2409-14

3 Jansen PAF, Gribnau FWJ, Schulte BPM, Poels EFJ. Contribution of inappropriate treatment for hypertension to pathogenesis of stroke in the elderly. Br Med f 1986;293:914-6.

(Accepted 5 June 1987)

Medical Unit and Department of Radiology, St Mary's Hospital, London W2 M SUTTERS, MA, MRCP, research registrar

M A AL-KUTOUBI, MD, FRCR, consultant radiologist

C J MATHIAS, DPHIL, FRCP, Wellcome senior lecturer and consultant physician SIR STANLEY PEART, FRCP, FRS, professor of medicine

Correspondence and requests for reprints to: Dr Sutters.

\section{Cerebrospinal fluid fistula after lumbar puncture}

Cerebrospinal fluid leaking into the surrounding soft tissues is well known after lumbar puncture and is thought to be the most important factor in the genesis of postpuncture headache. We describe a unique case of hitherto unknown chronic external leak of cerebrospinal fluid through a fistula which developed after lumbar puncture.

\section{Case report}

A 16 year old boy with a clinical diagnosis of cauda equina syndrome was subjected to lumbar puncture. An 18 gauge needle was introduced in the L3-4 intervertebral space in the left lateral position and about $6 \mathrm{ml}$ fluid collected in a single prick with no evidence of traumatic tap. Simultaneously $6 \mathrm{ml}$ lipid soluble contrast medium was introduced. Subsequent myelography showed nothing abnormal. Following the custom in this hospital, we did not remove the lipid contrast after the myelography. The patient lay prone for the next three hours with his feet raised.

Twenty four hours after the lumbar puncture cerebrospinal fluid started oozing through the puncture wound. Pressure dressings with adhesive tape did not help. Epidural blood patching ${ }^{1}$ was also tried but without success. Two months later the leak persisted and the fistula was sutured subcutaneously. The leak stopped for three days but then started again. After three months of persistent leak the patient was treated by absolute bed rest in the prone position with the head down and cisternal punctures were done daily for seven days, $10-20 \mathrm{ml}$ cerebrospinal fluid being withdrawn each time. This completely stopped the leak within a week, and after a further two weeks' bed rest in the same position the patient was discharged. No leak was detected over the next eight months.

\section{Comment}

Internal cerebrospinal fluid leak of clinical importance is manifested by postpuncture headache. The average incidence of headache after lumbar puncture is $41 \%,{ }^{2}$ but this may be appreciably reduced by preventive measures. ${ }^{3}$ These measures fail in about a third of patients, however, who therefore have clinically significant cerebrospinal fluid leak into the surrounding soft tissues. External cerebrospinal fluid fistulas occur in patients with head injury, infections, neoplasms, and hydrocephalus ${ }^{4}$ and present as rhinorrhoea or otorrhoea, but there is no definite report of such a fistula developing after a lumbar puncture. ${ }^{5}$

1 Ostheimer GW, Palahniuk RJ, Shnider SM. Epidural blood patch for post lumbar puncture headache. Anesthesiology 1974;41:307-8.

2 Brocker RJ. Technique to avoid spinal-tap headache. JAMA 1958;168:261-3.

3 Carbaat PAT, Van Crevel H. Lumbar puncture headache: controlled study of preventive effect of 24 hours' bed rest. Lancet 1981;ii:1133-5.

4 Crow HJ, Keogh C, Northfield DWC. The localisation of cerebrospinal fluid fistulae. Lance 1956;ii:325-7.

5 Clough C, Pearce JMS. Lumbar puncture. Br Med F 1980;280:297-9.

(Accepted 16 February 1987)

Department of Neurology, King George's Medical College, Lucknow, India

ALOK MOHAN KAR, MD, DM, professor of neurology

SUNIL PRADHAN, MD, DM, senior resident in neurology

PIYUSH MITTAL, MS, MCH, pool officer in neurosurgery

Correspondence to: Dr Kar.

\section{Equality in death: disappearance of differences in postneonatal mortality between northern and southern regions of England and Wales}

Evidence is increasing that the state of health in adulthood is closely linked to that in childhood. ${ }^{1-3}$ For many years postneonatal mortality was higher in the industrial north of England than the more affluent south because of its greater proportion of working class families. After a plateau in the figures for England and Wales in the 1960 s, however, postperinatal mortality fell during the $1970 \mathrm{~s} .{ }^{4}$ We therefore looked at whether this fall also applied to postneonatal mortality and examined the present trend in northern and southern regions of England and Wales.

\section{Methods and results}

All figures were obtained from the Registrar General's annual statistical reviews and surveys (DH3 series) of the Office of Population Censuses and Surveys. Northern regions were taken as the north east, Yorkshire, the east Midlands, the west Midlands, the north west, and Wales. Southern regions were taken as East Anglia, London and the south east, the south, and the south west.

The figure shows the trends in postneonatal mortality in the northern and southern regions. Rates remained higher in the northern regions until the fall in the early 1970s, which brought equality with the south of England, and this persisted. Rates in the south of England remained the same after 1960. The fall in postneonatal mortality in the 1970 s in northern regions fully explained the fall in the figures for England and Wales, which happened at the same time.

\section{Comment}

Postneonatal mortality shows the effects of environmental conditions during the first year of life free from the effects of fetomaternal interactions 